\title{
The relationship between breast cancer molecular subtypes and mast cell populations in tumor microenvironment
}

\author{
Anna Glajcar ${ }^{1}$ - Joanna Szpor ${ }^{1}$ - Agnieszka Pacek ${ }^{1} \cdot$ Katarzyna Ewa Tyrak $^{2}$ • \\ Florence Chan $^{1}$ • Joanna Streb ${ }^{3}$ - Diana Hodorowicz-Zaniewska ${ }^{4}$ - Krzysztof Okoń ${ }^{1}$
}

Received: 24 October 2016 / Revised: 28 February 2017 / Accepted: 2 March 2017 /Published online: 18 March 2017

(C) The Author(s) 2017. This article is published with open access at Springerlink.com

\begin{abstract}
Mast cells (MCs) are a part of the innate immune system. The MC functions toward cancer are partially based on the release of chymase and tryptase. However, the MC effect on breast cancer is controversial. The aim of our study was to investigate the presence of MCs in breast cancer tumors of different molecular subtypes and their relationships with other pathological prognostic factors. Tryptase- and chymase-positive mast cell densities were evaluated by immunohistochemistry in 108 primary invasive breast cancer tissue samples. Positive cells were counted within the tumor bed and at the invasive margin. For all analyzed MC subpopulations, we observed statistically significant differences between individual molecular subtypes of breast cancer. The significantly higher numbers of intratumoral chymase- and tryptase-positive mast cells were observed in luminal A and luminal B tumors compared to triple-negative and HER2+ non-luminal lesions. A denser MC infiltration was associated with lower tumor grade, higher ER and PR expression, lower proliferation rate as well as the lack of HER2 overexpression. The results obtained in our study indicate a possible association of chymase- and tryptase-positive MCs with more favorable cancer immunophenotype and with beneficial prognostic indicators in breast cancer.
\end{abstract}

Krzysztof Okoń

k.okon@uj.edu.pl

1 Department of Pathomorphology, Jagiellonian University Medical College, ul. Grzegórzecka 16, 31-531 Kraków, Poland

2 2nd Department of Internal Medicine, Jagiellonian University Medical College, Kraków, Poland

3 Department of Oncology, Jagiellonian University Medical College, Kraków, Poland

4 Department of General, Oncological, and Gastrointestinal Surgery, Jagiellonian University Medical College, Kraków, Poland
Keywords Mast cells $\cdot$ Breast cancer $\cdot$ Molecular classification

\section{Introduction}

Breast cancer is the most common cancer in females in the developed world. It is heterogeneous in terms of prognosis, morphology, and molecular biology; on the basis of its gene expression pattern, four main molecular subtypes were distinguished: luminal A, luminal B, HER2 non-luminal, and basallike. This classification may be emulated by an immunohistochemical panel, which became a standard in routine pathology $[1,2]$.

Tumor microenvironment consists of fibroblast, endothelial, and immune cells as well as extracellular matrix (ECM) in the immediate surroundings of cancer. It influences anti-tumor host defense, tumor development, neoangiogenesis, and metastatic propensity, and may affect patient's outcome [1-3].

Mast cells (MCs) are bone marrow-derived cells commonly associated with allergic reactions and responses to parasitic infestations. MC granules store numerous mediators, including heparin, histamine, proteases, chemokines, and growth factors, which are released upon MC activation and contribute to tissue repair, wound healing, and angiogenesis. They modulate functions of other immune cells by either enhancing immunologic response or inducing immune tolerance. MCs are also one of the first cells to infiltrate cancer and can either promote or suppress tumor growth [4-8].

Proteases constitute approximately one fourth of MCs protein content. Based on the expression of chymase and tryptase, the mast-cell-specific serine proteases, human $\mathrm{MCs}$ are divided into $\mathrm{MC}_{\mathrm{T}}$, which expresses only tryptase and $\mathrm{MC}_{\mathrm{TC}}$, which expresses both tryptase and chymase. These populations predominate in different 
anatomical locations and vary according to their functions $[4,6,9]$. Tryptase participates in ECM remodeling and is a potent proangiogenic factor, in part by protease-activated-receptor 2 (PAR-2) activation [9-11]. MC tryptase was also reported to activate tumorassociated fibroblasts [12]. Chymase is thought to be important mainly for ECM remodeling; however, it may also induce angiogenesis by activating metalloproteinases (MMPs), such as MMP-9, which releases proangiogenic mediators from stroma $[6,12,13]$.

Some MC proteases are stored in complexes with heparin [14]. Heparin suppresses proliferation and reduces the number of breast cancer cell colonies. It was hypothesized that heparin might interrupt interactions between tumor-associated fibroblasts and cancer cells, thus impairing tumor development [15].

The aim of the study was to investigate the density of MCs expressing tryptase and chymase in breast cancers of different molecular subtypes and to examine their relationships with more standard prognostic factors.

Preliminary results from this study were presented at the 6th Jagiellonian University Medical College Doctoral Students' Conference.

\section{Materials and methods}

\section{Materials}

The material consisted of routinely processed, formalinfixed paraffin-embedded primary invasive breast carcinomas diagnosed between 2002 and 2014. The archival hematoxylin-eosin-stained slides were re-evaluated and representative, well-preserved specimens were chosen for immunohistochemistry. For nuclear grading, Nottingham Histologic Grade system was used, while staging was performed according to 2010 AJCC system [16].

\section{Immunohistochemistry}

Immunohistochemistry for tryptase, chymase, estrogen receptor (ER), progesterone receptor (PR), and Ki67 protein was performed according to the protocol routinely used in our laboratory. The selected blocks were cut into $4-\mu \mathrm{m}$-thick sections. Antigen retrieval was performed by incubating the slides in citrate buffer $(\mathrm{pH} 6.0 ; 0.01 \mathrm{M})$ or EDTA $(\mathrm{pH} 8.0 ; 0.01 \mathrm{M})$ at $97{ }^{\circ} \mathrm{C}$ in a water bath for 40 and $30 \mathrm{~min}$, respectively, or by enzymatic digestion with proteinase $\left(21^{\circ} \mathrm{C}, 7 \mathrm{~min}\right)$. Primary antibodies used in the study are listed in Table 1.

UltraVision Quanto detection system (LabVision; ThermoScientific, USA) and 3,3'-diaminobenzidine as chromogen were used, and the slides were counterstained with Mayer hematoxylin (Thermo Fisher Scientific, Waltham, USA) and coverslipped.

Immunohistochemistry for HER2 was performed on BenchMark BMK Classic autostainer (Ventana, USA) using UltraVIEW DAB Detection Kit (Ventana Medical Systems Inc., USA).

For specimens with HER2 status $2+$ by immunohistochemistry, fluorescence in situ hybridization (FISH) was conducted. FISH was performed using a PathVysion HER-2 DNA Probe Kit II (Abbott Molecular, USA) according to the manufacturer's protocol. In short, paraffin blocks were cut into 4- $\mu \mathrm{m}$-thick sections. Hybridization was performed at $37^{\circ} \mathrm{C}$ for 14 to $18 \mathrm{~h}$ with a locus specific identifier (LSI) DNA probe ( $226 \mathrm{~kb})$ SpectrumOrange directly labeled (Abbott Molecular, USA) and a Chromosome Enumeration Probe 17 (CEP17) satellite DNA probe $(\sim 5.4 \mathrm{~kb})$ SpectrumGreen directly labeled (Abbott Molecular, USA). 4,6-Diamino-2-phenylidole was used as nuclear counterstain. The LSI HER-2/neu and CEP17 signals were counted on fluorescence microscope equipped with specific filter sets and HER-2/neu to CEP17 ratio >2.0 was considered as HER2/neu overexpression [17].
Table 1 Antibodies used in the study

\begin{tabular}{|c|c|c|c|c|c|}
\hline & Clone & Dilution & $\begin{array}{l}\text { Antigen } \\
\text { retrieval }\end{array}$ & $\begin{array}{l}\text { Incubation } \\
\text { time (min) }\end{array}$ & Manufacturer \\
\hline Tryptase & AA1 & $1: 100$ & Proteinase & 60 & $\begin{array}{l}\text { Novocastra (Leica } \\
\text { Biosystems, Germany) }\end{array}$ \\
\hline Chymase & $\mathrm{CC} 1$ & $1: 100$ & Citrate & 30 & $\begin{array}{l}\text { LabVision } \\
\quad \text { (ThermoScientific, USA) }\end{array}$ \\
\hline $\begin{array}{l}\text { Estrogen } \\
\text { receptor }\end{array}$ & $6 \mathrm{~F} 11$ & $1: 25$ & Citrate & 60 & $\begin{array}{l}\text { Novocastra (Leica } \\
\text { Biosystems, Germany) }\end{array}$ \\
\hline $\begin{array}{l}\text { Progesterone } \\
\text { receptor }\end{array}$ & PgR636 & $1: 50$ & Citrate & 60 & Dako, USA \\
\hline Ki67 & MIB-1 & $1: 100$ & EDTA & 60 & Dako, USA \\
\hline HER2/neu & PATHWAY4B5 & & & & $\begin{array}{l}\text { Ventana Medical System } \\
\text { Inc., USA }\end{array}$ \\
\hline
\end{tabular}




\section{Evaluation of immunostaining}

The slides stained for tryptase and chymase were scanned on Nikon Labophot-2 optical microscope (Tokyo, Japan) at low magnification $(\times 100)$, and the areas with the highest number of positive cells were chosen. Then, positively stained cells were counted in five high-power fields (HPF) $\left(400 \times 0.2 \mathrm{~mm}^{2}\right.$ field area), which represented $1 \mathrm{~mm}^{2}$ of the examined tissue. The positive cells located no further than 1 HPF from the tumor edge were regarded as invasive margin, while positive cells located within neoplastic tissue further than 1 HPF from the tumor edge inwards were considered as intratumoral population.

Positive ER and PR expression were set when $\geq 1 \%$ of neoplastic cells showed positive immunostaining. The threshold for discriminating between low and high Ki67 expression was set at $\geq 14 \%$ of positive cells. Scoring of the HER 2 stain was performed by standard method [17].

\section{Definition of breast cancer molecular subtypes}

The cases were classified into molecular subtypes according to St Gallen 2013 International Expert Consensus: luminal A (ER+ and PR $\geq 20 \%$, Ki67 < 14\%, HER2-), luminal B/ HER2 - (ER+, HER2 - with PR $<20 \%$ and/or Ki67 $\geq 14 \%)$, luminal B/HER2+ (ER+ or PR+, HER2+), HER2+ non-luminal (ER $-/ \mathrm{PR}-/ \mathrm{HER} 2+$ ), and triple-negative breast cancer (ER-/PR - HER2-) [18].

\section{Statistical analysis}

To assess the differences in positive cells' infiltrate between groups, ANOVA Kruskal-Wallis and Mann-Whitney $U$ tests were performed. The correlations between groups were evaluated by using Spearman rank test. All analyses were performed using Statistica 10 (StatSoft Inc., USA). $p$ values $<0.05$ were considered statistically significant.

\section{Results}

\section{Study group}

The study group consisted of 108 cases. The mean age of patients at the time of diagnosis was 55.3 years, ranging from 29 to 87 years. Sixty cases (55.5\%) were stage pT1, 45 cases (41.7\%) pT2, and 3 cases (2.8\%) pT3. Lymph node status was pN0 in 54 cases $(50.0 \%)$, pN1 in 31 cases $(28.7 \%)$, pN2 in 9 cases $(8.3 \%)$, and $\mathrm{pN} 3$ in 13 cases $(12.0 \%)$.

Distribution of molecular subtypes was as follows: luminal $\mathrm{A}$ in 30 cases (27.8\%), luminal B/HER2 - in 19 cases (17.6\%), luminal B/HER2 + in 10 cases (9.3\%), HER2+ non-luminal (HER2+) in 20 cases (18.5\%), and triple-negative breast cancer (TNBC) in 29 cases $(26.8 \%)$. On the basis of the histologic type, 91 cases (84.3\%) were classified as "not otherwise specified" (NOS), 15 cases (13.9\%) as lobular, and 2 cases (1.8\%) as "other." Nottingham Histologic Grade was $\mathrm{G} 1$ in 17 cases (15.7\%), G2 in 37 cases (34.3\%), and G3 in 54 cases $(50 \%)$. The patients and tumor characteristics are shown in Table 2.

\section{MC subpopulations in different breast cancer subtypes}

First, we investigated whether the mast cell counts differed between cancers of luminal (ER+ or PR+) and non-luminal (ER- and $\mathrm{PR}-$ ) immunophenotype. A statistically significant difference was observed for both chymase- and tryptasepositive MCs in either intratumoral location or at the invasive margin (Fig. 1). In all cases, the luminal subtype of tumors was associated with relatively higher MC count (Table 3).

Thorough analysis of each of the investigated MC populations showed significant differences in the density of infiltration between molecular subtypes of cancer; this was most evident for intratumoral cells. The number of intratumoral

Table 2 Clinicopathologic features of the study group

\begin{tabular}{|c|c|c|}
\hline Characteristic & Number of cases & Percent \\
\hline \multicolumn{3}{|l|}{ Age } \\
\hline \multicolumn{3}{|l|}{ Range: $29-87$} \\
\hline \multicolumn{3}{|l|}{ Mean: 55.3} \\
\hline \multicolumn{3}{|l|}{ Tumor size } \\
\hline pT1 & 60 & 55.5 \\
\hline pT2 & 45 & 41.7 \\
\hline pT3 & 3 & 2.8 \\
\hline \multicolumn{3}{|l|}{ Lymph node status } \\
\hline $\mathrm{pN} 0$ & 54 & 50.0 \\
\hline $\mathrm{pN} 1$ & 31 & 28.7 \\
\hline $\mathrm{pN} 2$ & 9 & 8.3 \\
\hline $\mathrm{pN} 3$ & 13 & 12.0 \\
\hline \multicolumn{3}{|c|}{ Nottingham Histologic Grade } \\
\hline G1 & 17 & 15.7 \\
\hline G2 & 37 & 34.3 \\
\hline G3 & 54 & 50.0 \\
\hline \multicolumn{3}{|l|}{ Histological type } \\
\hline Ductal & 91 & 84.3 \\
\hline Lobular & 15 & 13.9 \\
\hline Other & 2 & 1.8 \\
\hline \multicolumn{3}{|l|}{ Molecular subtype } \\
\hline Luminal A & 30 & 27.8 \\
\hline Luminal B & 19 & 17.6 \\
\hline Luminal B/ HER2+ & 10 & 9.3 \\
\hline HER2+ non-luminal & 20 & 18.5 \\
\hline Triple negative & 29 & 26.8 \\
\hline
\end{tabular}


Table 3 MC densities in breast cancers of different molecular subtype, immunophenotype, Ki67, and HER2 expression

\begin{tabular}{|c|c|c|c|c|c|c|c|c|}
\hline & \multicolumn{4}{|c|}{ Chymase } & \multicolumn{4}{|l|}{ Tryptase } \\
\hline & \multicolumn{2}{|c|}{ Intratumoral } & \multicolumn{2}{|c|}{ Invasive margin } & \multicolumn{2}{|c|}{ Intratumoral } & \multicolumn{2}{|c|}{ Invasive margin } \\
\hline & $\begin{array}{l}\text { Mean } \\
(\mathrm{SD})\end{array}$ & $p$ & $\begin{array}{l}\text { Mean } \\
(\mathrm{SD})\end{array}$ & $p$ & $\begin{array}{l}\text { Mean } \\
(\mathrm{SD})\end{array}$ & $p$ & $\begin{array}{l}\text { Mean } \\
(\mathrm{SD})\end{array}$ & $p$ \\
\hline \multicolumn{9}{|l|}{ Molecular subtype } \\
\hline Luminal A & $\begin{array}{l}22.59 \\
(10.38)\end{array}$ & $<0.001$ & $\begin{array}{l}23.21 \\
(7.87)\end{array}$ & $<0.025$ & $\begin{array}{l}40.40 \\
(16.97)\end{array}$ & $<0.001$ & $\begin{array}{l}36.27 \\
(20.62)\end{array}$ & $<0.015$ \\
\hline Luminal B & $\begin{array}{l}27.72 \\
(12.76)\end{array}$ & & $\begin{array}{l}25.68 \\
(11.95)\end{array}$ & & $\begin{array}{l}36.94 \\
(17.56)\end{array}$ & & $\begin{array}{l}38.74 \\
(19.97)\end{array}$ & \\
\hline Luminal B/HER2+ & $\begin{array}{l}20.80 \\
(12.45)\end{array}$ & & $\begin{array}{l}19.50 \\
(7.55)\end{array}$ & & $\begin{array}{l}31.10 \\
(20.89)\end{array}$ & & $\begin{array}{l}26.70 \\
(11.49)\end{array}$ & \\
\hline HER2+ non-luminal & $\begin{array}{l}15.30 \\
(7.89)\end{array}$ & & $\begin{array}{l}18.70 \\
(9.76)\end{array}$ & & $\begin{array}{l}25.90 \\
(11.43)\end{array}$ & & $\begin{array}{l}24.65 \\
(9.24)\end{array}$ & \\
\hline Triple negative & $\begin{array}{l}14.56 \\
(9.82)\end{array}$ & & $\begin{array}{l}19.03 \\
(7.35)\end{array}$ & & $\begin{array}{l}22.50 \\
(13.42)\end{array}$ & & $\begin{array}{l}27.17 \\
(11.28)\end{array}$ & \\
\hline \multicolumn{9}{|l|}{ Immunophenotype } \\
\hline Luminal & $\begin{array}{l}23.89 \\
(11.64)\end{array}$ & $<0.001$ & $\begin{array}{l}23.38 \\
(9.43)\end{array}$ & $<0.005$ & $\begin{array}{l}37.72 \\
(17.86)\end{array}$ & $<0.001$ & $\begin{array}{l}35.44 \\
(19.34)\end{array}$ & $<0.004$ \\
\hline Non-luminal & $\begin{array}{l}14.87 \\
(8.97)\end{array}$ & & $\begin{array}{l}18.90 \\
(8.32)\end{array}$ & & $\begin{array}{l}23.92 \\
(12.61)\end{array}$ & & $\begin{array}{l}26.14 \\
(10.46)\end{array}$ & \\
\hline \multicolumn{9}{|l|}{ HER2 overexpression } \\
\hline No & $\begin{array}{l}20.91 \\
(11.88)\end{array}$ & NS & $\begin{array}{l}22.25 \\
(9.15)\end{array}$ & $<0.025$ & $\begin{array}{l}32.99 \\
(17.69)\end{array}$ & NS & $\begin{array}{l}33.49 \\
(18.01)\end{array}$ & $<0.015$ \\
\hline Yes & $\begin{array}{l}17.13 \\
(9.79)\end{array}$ & & $\begin{array}{l}18.97 \\
(8.96)\end{array}$ & & $\begin{array}{l}27.63 \\
(15.08)\end{array}$ & & $\begin{array}{l}25.33 \\
(9.89)\end{array}$ & \\
\hline \multicolumn{9}{|l|}{ Ki67 expression } \\
\hline Low & $\begin{array}{l}22.41 \\
(10.97) \\
18.56 \\
(11.47)\end{array}$ & NS & $\begin{array}{l}22.79 \\
(8.27) \\
20.43 \\
(9.44)\end{array}$ & NS & $\begin{array}{l}39.17 \\
(16.29) \\
27.68 \\
(16.28)\end{array}$ & $<0.001$ & $\begin{array}{l}34.89 \\
(19.61) \\
29.22 \\
(14.62)\end{array}$ & NS \\
\hline
\end{tabular}

chymase-positive MCs was the highest in luminal B cancers, which differed significantly from TNBC $(p<0.002)$ and HER2+ non-luminal $(p<0.025)$ tumors. Luminal A cancers contained significantly more chymase-positive MCs than TNBC cancers $(p<0.04)$. The intratumoral tryptase-positive MC density was the highest in luminal A tumors and was significantly higher than that in TNBC $(p<0.001)$ and HER2+ non-luminal $(p<0.04)$ cases. The abundance of these cells was also significantly higher in luminal B as compared to TNBC tumors $(p<0.015)$. There was a significant difference in $\mathrm{MC}$ density at the invasion front between all the molecular breast cancer subtypes, but no significant difference in post hoc analysis was observed (Fig. 2, Table 3).

The number of MCs at the invasive margin, either chymase- or tryptase-positive, was significantly increased in tumors without HER2 overexpression $(p<0.025$ and $p<0.015$, respectively) compared to that in HER2 overexpressed tissues (Table 3).
We also observed also that intratumoral tryptase-positive MCs were strongly associated with tumors of low Ki67 expression $(p<0.001)$ (Table 3$)$.

The numbers of all investigated MC populations showed significant positive correlations with ER and PR expression, as well as a negative correlation with mitotic index. For investigated subpopulations, either in intratumoral area or at the invasion edge, tryptase-positive MCs correlated negatively with Ki67 expression. However, for chymase-positive MCs, such correlation was observed only within the tumor bed.

\section{MC subpopulations and other pathological prognostic factors}

Investigated tumors were stratified according to their size into tumors of diameter $\leq 2 \mathrm{~cm}(\mathrm{pT} 1)$ and $>2 \mathrm{~cm}(\mathrm{pT}>1)$. We observed statistically significant differences in tryptasepositive cell densities in both intratumoral compartment 

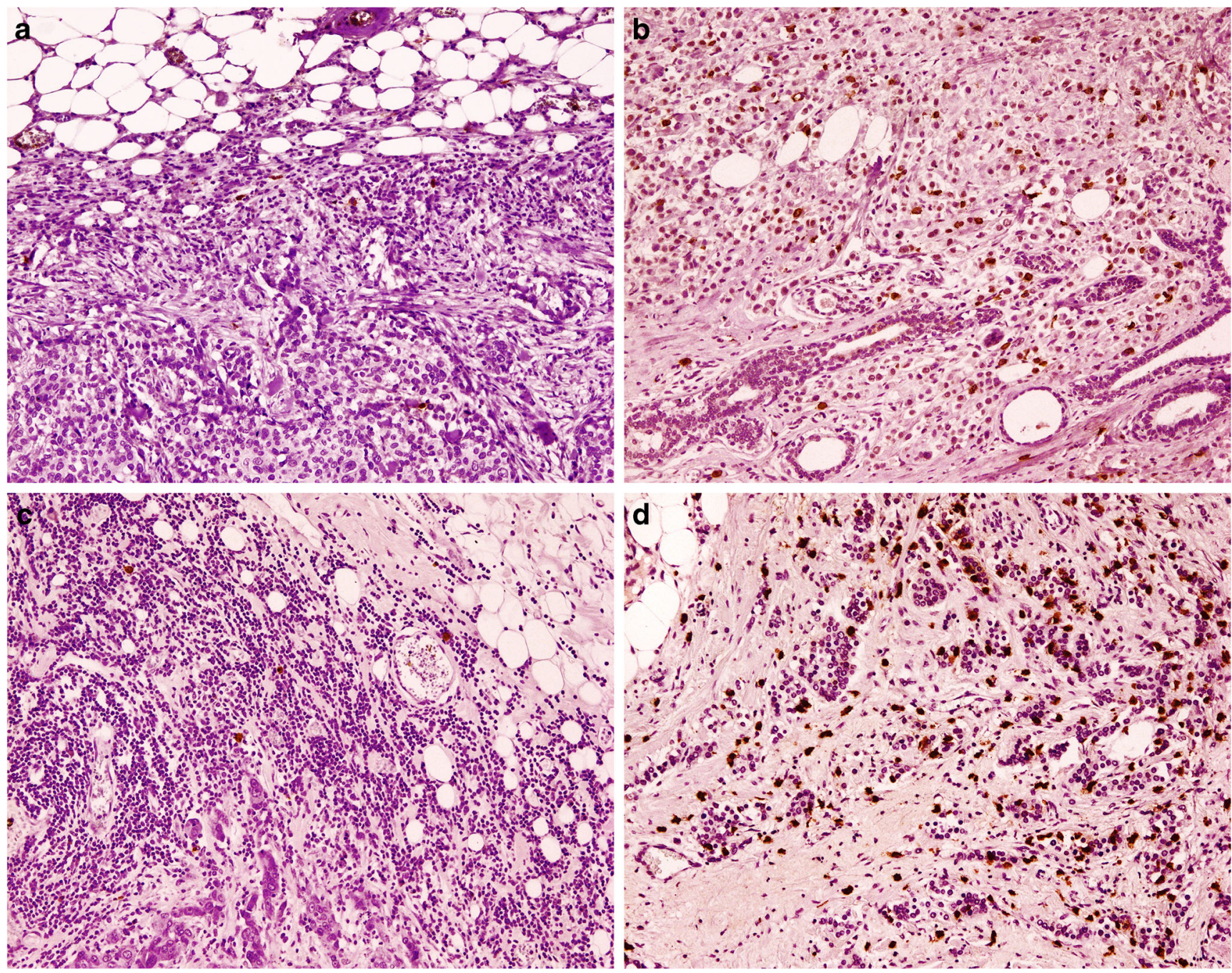

Fig. 1 Mast cells in invasive breast cancer. Low (a) and high (b) chymase-positive mast cells infiltration, low (c) and high (d) tryptase-positive mast cells infiltration. Immunohistochemistry for tryptase and chymase, magnification $\times 100$

$(p<0.008)$ and at the invasion front $(p<0.02)$ between the two groups. The intratumoral tryptase-positive MC density was higher in pT1 tumors (mean 35.5, SD 18.2) as compared to $\mathrm{pT}>1$ lesions (mean 26.6, SD 14.3). Similarly, for tryptasepositive MCs at the tumor margin, higher density was observed in smaller-sized cancers (pT1-mean 33.7, SD 17.2; pT $>1$-mean 28.1, SD 15.2). There were no statistically significant differences in MC densities between cases with and without nodal involvement.

There were significant differences in the densities of tryptase-positive cells, both in intratumoral compartment and at the invasive margin, as well as intratumoral chymasepositive cell count between tumors of different Nottingham Histologic Grades. The number of intratumoral chymasepositive cells was significantly higher in G1 $(p<0.015)$ and G2 $(p<0.008)$ tumors as compared to G3 lesions. Tryptasepositive $\mathrm{MC}$ densities for both intratumoral compartment and invasion front were significantly higher in G1 than in G3 cancers ( $p<0.015$ and $p<0.05$, respectively) (Fig. 3, Table 4).
In respect of tumor histological type, intratumoral tryptasepositive cells were significantly associated with lobular phenotype (Table 4).

\section{Discussion}

The studies concerning MC infiltration in various breast cancer molecular subtypes were scarce and the results were encumbered by varied subtype classifications. In our study, we noted that chymase- and tryptase-positive MC infiltration differed between breast cancers of respective molecular subtypes in both intratumoral area as well as at the invasive margin, and that higher MC numbers were associated with less aggressive cancer types. Similar to our results, della Rovere et al. observed high $\mathrm{MC}$ density in breast cancer expressing high levels of hormone receptors. As a result, the authors considered MC infiltration in this neoplasm as a protective factor against tumor progression, potentially due to MC cytolytic activity against malignant cells 
Fig. 2 Density of investigated MC subpopulations in breast cancer specimens representing different molecular subtypes: Lum A luminal A, Lum B luminal B/HER2-, Lum B/HER2 luminal B/HER2+, HER2 HER2+ nonluminal, $T N B C$ triple-negative subtype. Central point is the arithmetic mean, box is the arithmetic mean \pm standard error, and whisker is the arithmetic mean \pm standard deviation. ANOVA Kruskal-Wallis test, $p$ values are shown in Table 3
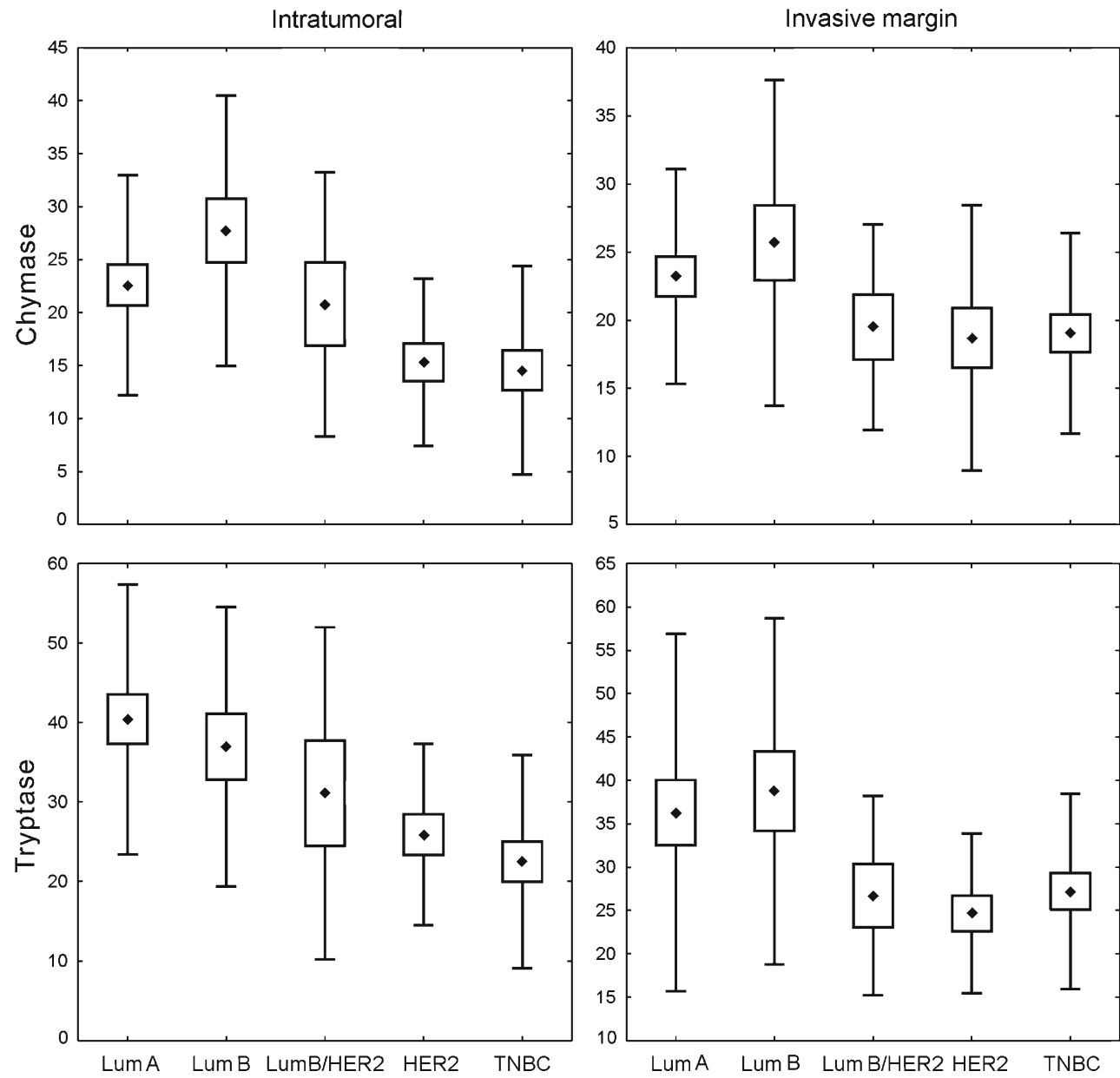

$[19,20]$. Raica et al. noted that density of intratumoral, but not peritumoral, tryptase-positive MCs was higher in luminal A, luminal B, and HER2-positive breast cancers compared to basal- like breast cancers [21]. This was partially analogous to our results, which suggested that non-luminal HER2-positive subtype was associated with low tryptase-positive MC content. In
Table 4 MC density according to tumor grade and breast cancer histological type

\begin{tabular}{|c|c|c|c|c|c|c|c|c|}
\hline & \multicolumn{4}{|c|}{ Chymase } & \multicolumn{4}{|l|}{ Tryptase } \\
\hline & \multicolumn{2}{|c|}{ Intratumoral } & \multicolumn{2}{|c|}{ Invasive margin } & \multicolumn{2}{|c|}{ Intratumoral } & \multicolumn{2}{|c|}{ Invasive margin } \\
\hline & $\begin{array}{l}\text { Mean } \\
(\mathrm{SD})\end{array}$ & $p$ & $\begin{array}{l}\text { Mean } \\
(\mathrm{SD})\end{array}$ & $p$ & $\begin{array}{l}\text { Mean } \\
(\mathrm{SD})\end{array}$ & $p$ & $\begin{array}{l}\text { Mean } \\
(\mathrm{SD})\end{array}$ & $p$ \\
\hline \multicolumn{9}{|c|}{ Nottingham Histologic Grade } \\
\hline 1 & $\begin{array}{c}24.41 \\
(10.24)\end{array}$ & $<0.002$ & $\begin{array}{l}23.06 \\
(8.67)\end{array}$ & NS & $\begin{array}{c}39.65 \\
(17.93)\end{array}$ & $<0.007$ & $\begin{array}{c}34.53 \\
(11.46)\end{array}$ & $<0.02$ \\
\hline 2 & $\begin{array}{c}23.46 \\
(11.81)\end{array}$ & & $\begin{array}{l}22.36 \\
(9.68)\end{array}$ & & $\begin{array}{c}34.44 \\
(17.59)\end{array}$ & & $\begin{array}{c}36.19 \\
(22.92)\end{array}$ & \\
\hline 3 & $\begin{array}{c}15.87 \\
(10.22)\end{array}$ & & $\begin{array}{l}20.09 \\
(8.98)\end{array}$ & & $\begin{array}{c}26.83 \\
(15.26)\end{array}$ & & $\begin{array}{c}26.78 \\
(10.72)\end{array}$ & \\
\hline \multicolumn{9}{|c|}{ Histological type } \\
\hline NOS & $\begin{array}{c}19.07 \\
(11.12)\end{array}$ & NS & $\begin{array}{l}20.69 \\
(8.57)\end{array}$ & NS & $\begin{array}{c}30.56 \\
(17.14)\end{array}$ & $<0.05$ & $\begin{array}{c}29.48 \\
(11.97)\end{array}$ & NS \\
\hline Lobular & $\begin{array}{c}24.79 \\
(11.65)\end{array}$ & & $\begin{array}{c}25.71 \\
(12.28)\end{array}$ & & $\begin{array}{c}38.73 \\
(15.93)\end{array}$ & & $\begin{array}{c}42.93 \\
(31.32)\end{array}$ & \\
\hline
\end{tabular}


the quoted study, significant correlations between peritumoral tryptase-positive MCs and lymphatic microvessel densities were found in luminal A and basal-like cancers. Such observation might indicate $\mathrm{MC}$ involvement in lymphangiogenesis and lymphovascular spreading of breast cancer, particularly of luminal A type [21]. Other studies also outlined the correlation between tryptase-positive MCs and microvessel density in breast cancer [22, 23].

We observed that all analyzed populations of MCs correlated positively with ER and PR expression and negatively with mitotic index. Additionally, tryptase-positive MCs both of the intratumoral area and at the invasion front were negatively associated with tumor size, while tryptase-positive as well as intratumoral chymase-positive MCs showed an inverse correlation with Ki67 expression. These findings supported the aforementioned hypothesis of the protective role assumed by MCs against cancer progression. Similarly, other studies also suggested a negative correlation of tryptasepositive MCs with tumor size [24], along with a positive correlation with PR [25] and ER expression [24]. Although several studies failed to show independent prognostic significance of MCs in breast cancer [24-26], and few works have even shown that peritumoral MC infiltration was associated with poor short-term survival [27], MCs were still proposed by some authors as an additive favorable prognostic factor $[19,25]$. It was further postulated that even a single MC in tumor surrounding might have a beneficial impact on the prognosis [28]. Rajput et al. observed a positive but not significant correlation between MCs and HER2 expression [28]. However, our study suggested that chymase- and tryptasepositive MC densities at the tumor front were associated with tumors that did not indicate HER2 overexpression. Some other studies observed an inverse correlation between tryptasepositive MCs and Ki67 expression [24], while others did not [19]. Contrary to our results and the aforementioned literature, Ranieri et al. did not find any associations between MC number and tumor size, histological grade, ER/PR status, or HER2 overexpression in early breast cancer [23].

Our study indicated that low- and intermediate-grade breast cancers contained high numbers of MCs in both intratumoral location and at the invasive margin. In consistence with our results, some authors reported that tryptase-positive MCs correlated negatively with tumor histological Elston grade [24, 25]. A plausible explanation could be that low-grade breast cancer elicited more effective innate immune response, or that high-grade cancer suppressed such response. Strikingly, Xiang et al. observed more numerous peritumoral MCs in G3 breast cancers than lower grades, and reported more intensive tryptase immunostaining in the surrounding of nodepositive tumors as compared to node-negative ones. In this experimental study, tryptase itself did not increase proliferative activity of breast cancer cell lines. However, in the presence of heparin, tryptase increased cancer cell migration and expression of activated MMP-1. As tryptase was activated by

Table 5 Immunohistochemical studies, which evaluated mast cells in breast cancer

\begin{tabular}{|c|c|c|c|c|}
\hline Authors & Material & $\begin{array}{l}\text { Mast cells' } \\
\text { marker }\end{array}$ & Conclusions & Reference \\
\hline $\begin{array}{l}\text { Bowers H. et al., } \\
1979\end{array}$ & $\begin{array}{l}\text { Axillary lymph nodes of } 43 \\
\text { breast cancer patients }\end{array}$ & $\begin{array}{l}\text { Toluidine } \\
\text { blue }\end{array}$ & Higher MC number is associated with better patients' survival & {$[30]$} \\
\hline $\begin{array}{l}\text { Samoszuk M., } \\
\text { Corwin M., } \\
2003\end{array}$ & $\begin{array}{l}35 \text { breast cancer tissue sections } \\
\text { of varying stages }\end{array}$ & Tryptase & $\begin{array}{l}\text { A tendency toward peritumoral accumulation of MCs in preinvasive } \\
\text { and intratumoral accumulation in invasive tumors }\end{array}$ & {$[31]$} \\
\hline $\begin{array}{l}\text { Amini RM. et al., } \\
2007\end{array}$ & $\begin{array}{l}234 \text { invasive breast cancer } \\
\text { tissues }\end{array}$ & Tryptase & $\begin{array}{l}\text { MCs are associated with estrogen receptor positivity and low tumor } \\
\text { grade }\end{array}$ & {$[25]$} \\
\hline $\begin{array}{l}\text { della Rovere F. } \\
\text { et al., } 2007\end{array}$ & $\begin{array}{l}50 \text { cases of invasive ductal breast } \\
\text { cancer }\end{array}$ & $\begin{array}{r}\text { Alcian } \\
\text { blue }\end{array}$ & Higher MC content is associated with high hormone-receptive cancers & [19] \\
\hline $\begin{array}{l}\text { Ribatti D. et al., } \\
2007\end{array}$ & $\begin{array}{l}80 \text { sentinel lymph nodes of } \\
\text { breast cancer patients }\end{array}$ & Tryptase & $\begin{array}{l}\text { Higher } \mathrm{MC} \text { number in micrometastatic lymph nodes; MC quantity } \\
\text { increases with angiogenesis }\end{array}$ & {$[32]$} \\
\hline $\begin{array}{l}\text { Rajput A. et al., } \\
2008\end{array}$ & $\begin{array}{l}4444 \text { invasive breast cancer } \\
\text { tissues }\end{array}$ & CD117 & $\begin{array}{l}\text { Presence of MCs in tumor stroma associated with better patients' } \\
\text { survival }\end{array}$ & {$[28]$} \\
\hline $\begin{array}{l}\text { Ranieri G. et al., } \\
2009\end{array}$ & $\begin{array}{l}88 \text { breast cancer patients' biopsy } \\
\text { specimens }\end{array}$ & Tryptase & MCs are associated with angiogenesis & {$[23]$} \\
\hline $\begin{array}{l}\text { Xiang M. et al., } \\
2010\end{array}$ & 80 breast cancer tissues & Tryptase & $\begin{array}{l}\text { MC number positively correlated with tumor grade and was associated } \\
\text { with nodal involvement }\end{array}$ & {$[29]$} \\
\hline $\begin{array}{l}\text { Löfdahl B. et al., } \\
2012\end{array}$ & $\begin{array}{l}190 \text { lymph-node-negative breast } \\
\text { cancer tissue samples }\end{array}$ & Tryptase & $\begin{array}{l}\text { Negative associations between MC number and adverse prognostic } \\
\text { factors }\end{array}$ & {$[24]$} \\
\hline $\begin{array}{l}\text { Raica M. et al., } \\
2013\end{array}$ & $\begin{array}{l}55 \text { ductal invasive breast cancer } \\
\text { tissues }\end{array}$ & Tryptase & $\begin{array}{l}\text { Interplay between MCs and lymph vessels is specific for each } \\
\text { molecular subtype of breast cancer }\end{array}$ & {$[21]$} \\
\hline $\begin{array}{l}\text { Marech I. et al., } \\
2014\end{array}$ & 105 cases of breast cancer & Tryptase & Mast cell tryptase is involved in angiogenesis & {$[22]$} \\
\hline
\end{tabular}


low $\mathrm{pH}$ and heparin, the authors concluded that tryptase promoted metastatic spread after microcirculation failed to remove acidic substances. This could potentially explain the higher $\mathrm{MC}$ count in more aggressive, more rapidly growing, grade 3 carcinomas observed in the study [29]. The findings from other immunohistochemical studies in breast cancer are summarized in Table 5.

Although the role of MCs in breast cancers has been investigated by several authors, the obtained results appeared to be ambiguous. Roy et al. [33] used an experimental model of arthritic mice for their study, which showed an elevated number of MCs within primary mammary tumors and at the sites of metastasis in comparison with the control group. This may be explained by the increased MC migration toward tumor and their activation within malignant lesion. MCs were suggested to attract stem cell factor (SCF) expressing breast cancer cells, thus facilitating the spread of the tumor. As SCF/c-kit signaling is considered to be one of the most potent chemoattractants and activators of MCs, SCF-positive neoplastic cells contributed, in turn, to subsequent infiltration, differentiation, and survival of MCs, which would eventually enhance metastatic potential of breast cancer [33]. Samoszuk et al. reported that MCs could counteract tumor hypoxia by releasing anticoagulants, which improved the blood flow. The authors also noted that tryptase-positive MCs in early breast cancer were more abundant in peritumoral stroma, while in invasive tumors, MCs were more extensively located within tumor tissue [31]. In the skin of breast cancer patients, chymase- and tryptase-positive MCs increased collagen production by interacting with dermal fibroblasts [34, 35]. It was also shown that MC tryptase has the capability to modify breast cancer microenvironment by converting fibroblasts into activated myofibroblasts, which, in turn, may promote tumor development. However, the accumulation of degranulated $\mathrm{MC}_{\mathrm{T}}$ at the invasion margin was interpreted as an evidence for protective role against cancer growth [36]. Bowers et al. observed significantly higher MC number in axillary lymph nodes of breast cancer patients who survived for longer than 60 months post-mastectomy, in comparison with patients with a shorter survival time span. As a result, the authors postulated that MCs might be involved in host tumor resistance [30]. In contrast, higher MC and microvessel counts in sentinel lymph nodes with micrometastases as compared to non-metastatic sentinel lymph nodes could suggest the participation of MCs in metastasis formation [32].

Mast cells were also investigated in other types of cancer. The MC count in squamous cell carcinoma of the lip was found to be higher compared to that in normal tissue. The distribution of MCs in this neoplasm differed with reference to location: within the tumor nest, $\mathrm{MC}_{\mathrm{T}}$ prevailed over $\mathrm{MC}_{\mathrm{TC}}$ cells, while $\mathrm{MC}_{\mathrm{TC}}$ predominated at the tumor front. It was postulated that the latter might influence cancer invasion
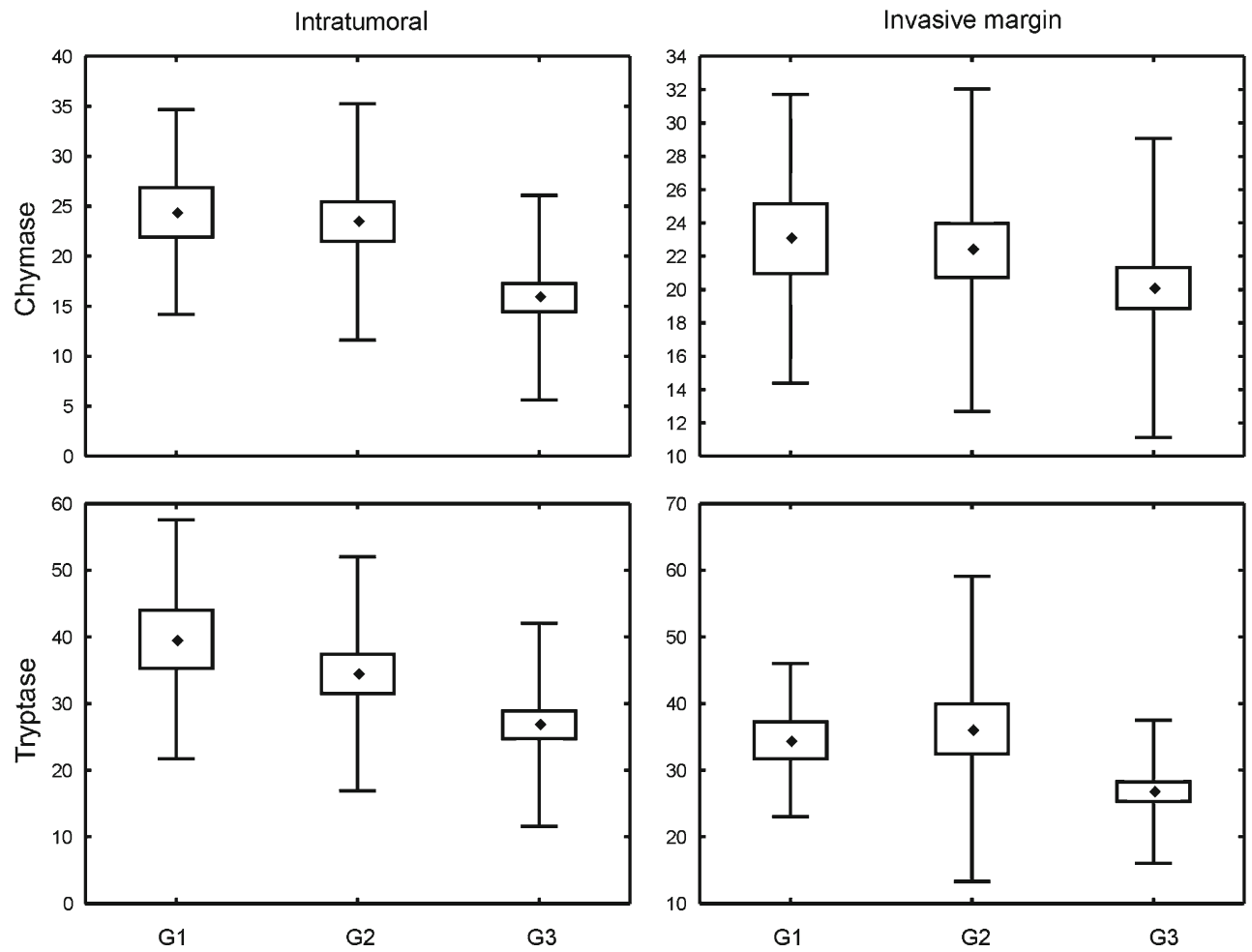

Fig. 3 Density of investigated MC subpopulations in breast cancer specimens representing different Nottingham Histologic Grade. Central point is the arithmetic mean, box is the arithmetic mean \pm standard error,

and whisker is the arithmetic mean \pm standard deviation. ANOVA Kruskal-Wallis test, $p$ values are shown in Table 4 
[37]. Mast cells displayed different phenotypes in normal, hyperplastic, and malignant prostate tissues, thus suggesting alteration in MC phenotypes and their involvement in pathogenesis of prostate cancer. Moreover, peritumoral tryptaseand chymase-positive MCs correlated with increasing Gleason score [38]. In the cervix, the overall MC level was stable in pre-cancer, but increased significantly in invasive cancer. The prevailing phenotype of mast cells was $\mathrm{MC}_{\mathrm{T}}$, and the authors hypothesized that this population may stimulate neovascularization and promote tumor progression and metastasis [39]. In addition, in patients on hemodialysis with renal cell carcinoma, $\mathrm{MC}_{\mathrm{T}}$ were also reported to predominate; an elevated SCF expression in specimens from hemodialyzed patients could potentially account for this $\mathrm{MC}_{\mathrm{T}}$ increase. $\mathrm{MC}_{\mathrm{T}}$ density correlated positively with proliferative index and PAR-2 expression in tumor cells [40]. Melanomas were noted to display lower numbers of both chymase- and tryptasepositive intratumoral MCs as compared to common and dysplastic nevi. Interestingly, the number of these cells increased from common to dysplastic nevi. The authors suggested that the observed decrease of MCs in malignant melanoma might be due to the self-sufficiency of this neoplasm to induce neoangiogenesis or to break the host defense barrier [41].

Several authors focused on the associations between MCs and angiogenesis, a phenomenon linked to progression in various neoplasms. In non-small cell lung carcinoma, $\mathrm{MC}_{\mathrm{TC}}$ correlated with blood vessel count both inside the tumor and at the invasive margin. In contrast, $\mathrm{MC}_{\mathrm{T}}$ number correlated with blood vessel count only at the invasive margin, potentially due to angiogenesis being associated mainly with $\mathrm{MC}_{\mathrm{TC}}$ density [42]. In an experimental mice skin cancer model, de Souza et al. observed that tumor MCs were recruited to the tumor microenvironment at their immature state, and that the number of both immature and mature MCs increased parallel to cancer progression. At early phases of tumor development, tryptase promoted neoangiogenesis, while in later stages it modulated vessel growth. Both chymase and tryptase expressions increased during tumor progression, and correlated with either MC maturation or new vessel formation, indicating the involvement of these two proteases in cancer progression [43]. Similarly in gastric carcinoma, tryptase- and chymase-positive MCs increased with stage and grade, and were associated with neoangiogenesis [44]. In colorectal adenocarcinoma, tryptase-positive MCs were found mainly in the immediate vicinity of blood vessels. However, as some of the tumor vessels lacked associated inflammatory cells, it was probable that inflammatory infiltration was not required for the induction of angiogenesis [45]. In contrast, neither tryptase- nor chymase-positive MC densities were related to microvessel counts in mesothelioma, though tryptase-positive MCs were associated with a better overall survival rate and a longer time till progression [46].

As it might be inferred from the aforementioned studies, $\mathrm{MC}$ contribution to tumor progression was observed in many neoplasms [12, 37, 38, 41, 43, 44]. However, in some tumors, MCs were regarded as protective factor [46], with their undefined role in breast cancer [24, 25, 29]. In various cancers MC distribution [37], as well as their prognostic significance, may vary depending on MC intratumoral $[40,41]$ or peritumoral [38] location, and in some cancers their increasing malignancy was reported to be associated with MC phenotype alteration $[37,38]$. In breast cancer, an increase in the number of nondegranulated MCs from normal to malignant tissue was observed [36]. MC functions are strongly dependent on microenvironmental factors, and both cytokines as well as hormones may affect even mature MCs and influence their number, activation, suppression, mediators' content, and phenotype $[4,47,48]$. Thus, it is not unlikely that on the basis on their functions and phenotype, in various cancers, the existence of several subpopulations of MCs could be considered, which might be partially analogous to distinction between M1 and M2 macrophages [47, 49].

In conclusion, our study outlined the associations of MCs with positive prognostic factors in breast cancer. We also observed that the breast cancer molecular subtypes differed in their chymase- and tryptase-positive MC content. However, further investigation is required to elucidate their impact on the breast cancer prognosis.

Compliance with ethical standards The study was approved by Jagiellonian University Committee of Bioethics (consent number 122.6120.149.2016).

Conflict of interest The authors declare that they have no conflicts of interest.

Funding This study was supported by Jagiellonian University Medical College (grant no. K/DSC/003589).

Open Access This article is distributed under the terms of the Creative Commons Attribution 4.0 International License (http:// creativecommons.org/licenses/by/4.0/), which permits unrestricted use, distribution, and reproduction in any medium, provided you give appropriate credit to the original author(s) and the source, provide a link to the Creative Commons license, and indicate if changes were made.

\section{References}

1. Esposito A, Criscitiello C, Curigliano G (2015) Highlights from the 14(th) St Gallen International Breast Cancer Conference 2015 in Vienna: dealing with classification, prognostication, and prediction refinement to personalize the treatment of patients with early breast cancer. Ecancermedicalscience 9:518. doi:10.3332/ecancer.2015.518 
2. Toss A, Cristofanilli M (2015) Molecular characterization and targeted therapeutic approaches in breast cancer. Breast Cancer Res 17(1):60. doi:10.1186/s13058-015-0560-9

3. Kozłowski J, Kozłowska A, Kocki J (2015) Breast cancer metastasis - insight into selected molecular mechanisms of the phenomenon. Postepy Hig Med Dosw 69:447-451

4. da Silva EZM, Jamur MC, Oliver C (2014) Mast cell function: a new vision of an old cell. Journal of Histochemistry \& Cytochemistry 62:698-738. doi:10.1369/0022155414545334

5. Ribatti D (2015) Mast cells as therapeutic target in cancer. Eur J Pharmacol. doi:10.1016/j.ejphar.2015.02.056

6. de Souza Junior DA, Santana AC, da Silva EZM, Oliver C, Jamur MC (2015) The role of mast cell specific chymases and tryptases in tumor angiogenesis. Biomed Res Int. doi:10.1155/2015/142359

7. Maciel TT, Moura IC, Hermine O (2015) The role of mast cells in cancers. F1000Prime Rep 7:9. doi: 10.12703/p7-09

8. Dyduch G, Kaczmarczyk K, Okoń K (2012) Mast cells and cancer: enemies or allies? Polish J Pathol 1:1-7

9. Pejler G, Rönnberg E, Waern I, Wernersson S (2011) Mast cell proteases: multifaceted regulators of inflammatory disease. Blood 115:4981-4990. doi:10.1182/blood-2010-01-257287

10. Sánchez-Hernández PE, Ramirez-Dueñas MG, Albarran-Somoza B, García-Iglesias T, del Toro-Arreola A, Franco-Topete R et al (2008) Protease-activated receptor-2 (PAR-2) in cervical cancer proliferation. Gynecol Oncol 108(1):19-26. doi:10.1016/j.ygyno. 2007.08.083

11. Ammendola M, Leporini C, Marech I, Gadaleta CD, Scognamillo G, Sacco R et al (2014) Targeting mast cells tryptase in tumor microenvironment: a potential antiangiogenetic strategy. Biomed Res Int. doi:10.1155/2014/154702

12. Coussens LM, Raymond WW, Bergers G, Laig-Webster M, Behrendtsen O, Werb Z et al (1999) Inflammatory mast cells upregulate angiogenesis during squamous epithelial carcinogenesis. Genes Dev 13(11):1382-1397. doi:10.1101/gad.13.11.1382

13. Noël A, Jost M, Maquoi E (2008) Matrix metalloproteinases at cancer tumor-host interface. Semin Cell Dev Biol 19(1):52-60. doi:10.1016/j.semcdb.2007.05.011

14. Humphries DE, Wong GW, Friend DS, Gurish MF, Qiu WT, Huang C et al (1999) Heparin is essential for the storage of specific granule proteases in mast cells. Nature 400(6746):769-772. doi:10.1038/23481

15. Samoszuk M, Kanakubo E, Chan JK (2005) Degranulating mast cells in fibrotic regions of human tumors and evidence that mast cell heparin interferes with the growth of tumor cells through a mechanism involving fibroblasts. BMC Cancer 5(1):121. doi:10.1186/ 1471-2407-5-121

16. Susan Lester AC, Chen Y-Y, Connolly JL, Fitzgibbons PL, Kleer C, Page DL, et al. Protocol for the examination of specimens from patients with invasive carcinoma of the breast. http://www.cap.org. Accessed 11 July 2016

17. Wolff AC, Hammond MEH, Hicks DG, Dowsett M, McShane LM, Allison KH et al (2013) Recommendations for human epidermal growth factor receptor 2 testing in breast cancer: American Society of Clinical Oncology/College of American Pathologists Clinical Practice Guideline Update. J Clin Oncol 31(31):3997-4013. doi: 10.1200/JCO.2013.50.9984

18. Goldhirsch A, Winer EP, Coates AS, Gelber RD, Piccart-Gebhart M, Thürlimann B et al (2013) Personalizing the treatment of women with early breast cancer: highlights of the St Gallen International Expert Consensus on the Primary Therapy of Early Breast Cancer. Ann Oncol 24(9):2206-2223. doi:10.1093/annonc/mdt303

19. della Rovere F, Granata A, Familiari D, D'Arrigo G, Mondello B, Basile G (2007) Mast cells in invasive ductal breast cancer: different behavior in high and minimum hormone-receptive cancers. Anticancer Res 27(4B):2465-2471
20. della Rovere F, Granata A, Monaco M, Basile G (2009) Phagocytosis of cancer cells by mast cells in breast cancer. Anticancer Res 29(8):3157-3161

21. Raica M, Cimpean AM, Ceauşu R, Ribatti D, Gaje P (2013) Interplay between mast cells and lymphatic vessels in different molecular types of breast cancer. Anticancer Res 33(3):957-964

22. Marech I, Ammendola M, Sacco R, Capriuolo GS, Patruno R, Rubini $R$ et al (2014) Serum tryptase, mast cells positive to tryptase and microvascular density evaluation in early breast cancer patients: possible translational significance. BMC Cancer 14:534 doi:10.1186/1471-2407-14-534

23. Ranieri G, Ammendola M, Patruno R, Celano G, Zito FA, Montemurro S et al (2009) Tryptase-positive mast cells correlate with angiogenesis in early breast cancer patients. Int $\mathrm{J}$ Oncol Spandidos Publications 35(1):115-120

24. Löfdahl B, Ahlin C, Holmqvist M, Holmberg L, Zhou W, Fjällskog M-L et al (2012) Inflammatory cells in node-negative breast cancer. Acta Oncol 51(5):680-686. doi:10.3109/0284186X.2011.652737

25. Amini R, Aaltonen K, Nevanlinna H, Carvalho R, Salonen L, Heikkilä P et al (2007) Mast cells and eosinophils in invasive breast carcinoma. BMC Cancer 7(1):165. doi:10.1186/1471-2407-7-165

26. Fisher ER, Sass R, Watkins G, Johal J, Fisher B (1985) Tissue mast cells in breast cancer. Breast Cancer Res Treat 5(3):285-291

27. Hartveit F, Thoresen S, Tangen M, Maartmann-Moe H (1984) Mast cell changes and tumour dissemination in human breast carcinoma. Invasion Metastasis 4(3):146-155

28. Rajput AB, Turbin DA, Cheang MC, Voduc DK, Leung S, Gelmon KA et al (2008) Stromal mast cells in invasive breast cancer are a marker of favourable prognosis: a study of 4,444 cases. Breast Cancer Res Treat 107(2):249-257. doi:10.1007/s10549-007-9546-3

29. Xiang M, Gu Y, Zhao F, Lu H, Chen S, Yin L (2010) Mast cell tryptase promotes breast cancer migration and invasion. Oncol Rep Spandidos Publications 23(3):615-619. doi:10.3892/or_00000676

30. Bowers HM, Mahapatro RC, Kennedy JW (1979) Numbers of mast cells in the axillary lymph nodes of breast cancer patients. Cancer 43(2):568-573

31. Samoszuk M, Corwin MA (2003) Mast cell inhibitor cromolyn increases blood clotting and hypoxia in murine breast cancer. Int J Cancer 107(1):159-163. doi:10.1002/ijc.11340

32. Ribatti D, Finato N, Crivellato E, Guidolin D, Longo V, Mangieri D et al (2007) Angiogenesis and mast cells in human breast cancer sentinel lymph nodes with and without micrometastases. Histopathology 51(6):837-842. doi:10.1111/j.1365-2559.2007. 02869.x

33. Roy LD, Curry JM, Sahraei M, Kidiyoor a, Besmer DM, Gruber HE et al (2012) Arthritis augments breast cancer metastasis: role of mast cells and SCF/c-Kit signaling. Cancer Res 72(2):1389-1389. doi:10.1158/1538-7445.AM2012-1389

34. Westbury CB, Freeman A, Rashid M, Pearson A, Yarnold JR, Short SC (2014) Changes in mast cell number and stem cell factor expression in human skin after radiotherapy for breast cancer. Radiother Oncol 111(2):206-211. doi:10.1016/j.radonc.2014.02.020

35. Reikki R, Harvima IT, Jukkola A, Ristile J, Oikarinen A (2004) The production of collagen and the activity of mast-cell chymase in crease in human skin after irradiation therapy. Exp Dermatol 13(6):364-371. doi:10.1111/j.0906-6705.2004.00164.x

36. Mangia A, Malfettone A, Rossi R, Paradiso A, Ranieri G, Simone $\mathrm{G}$ et al (2011) Tissue remodelling in breast cancer: human mast cell tryptase as an initiator of myofibroblast differentiation. Histopathology 58(7):1096-1106. doi:10.1111/j.1365-2559.2011. 03842.x

37. Rojas IG, Spencer ML, Martínez A, Maurelia MA, Rudolph MI (2005) Characterization of mast cell subpopulations in lip cancer. J Oral Pathol Med 34(5):268-273. doi:10.1111/j.1600-0714.2004.00297.x 
38. Globa T, Saptefiti L, Ceausu RA, Gaje P, Maria CA, Raica M (2014) Mast cell phenotype in benign and malignant tumors of the prostate. Pol J Pathol 65(2):147-153. doi:10.5114/PJP.2014.43965

39. Cabanillas-Saez A, Schalper JA, Nicovani SM, Rudolph MI (2002) Characterization of mast cells according to their content of tryptase and chymase in normal and neoplastic human uterine cervix. Int $\mathrm{J}$ Gynecol Cancer 12(1):92-98. doi:10.1046/j.1525-1438.2002. 01082.x

40. Watanabe SI, Miyata Y, Matsuo T, Mochizuki Y, Nishikido M, Hayashi T et al (2012) High density of tryptase-positive mast cells in patients with renal cell carcinoma on hemodialysis: correlation with expression of stem cell factor and protease activated receptor2. Hum Pathol 43(6):888-897. doi:10.1016/j.humpath.2011.07.019

41. Dyduch G, Okon K, Pescarini E (2011) Mast cells in melanocytic skin lesions. An immunohistochemical and quantitative study. Polish J Pathol 3:139-144

42. Ibaraki T, Muramatsu M, Takai S, Jin D, Maruyama $\mathrm{H}$, Orino $\mathrm{T}$ et al (2005) The relationship of tryptase- and chymase-positive mast cells to angiogenesis in stage I non-small cell lung cancer. Eur J Cardiothoracic Surg 28(4):617-621. doi:10.1016/j.ejcts.2005.06.020

43. de Souza DA, Toso VD, Campos MR de C, Lara VS, Oliver C, Jamur MC (2012) Expression of mast cell proteases correlates with mast cell maturation and angiogenesis during tumor progression. PLoS One 7(7):1-10. doi: 10.1371/journal.pone.0040790
44. Ribatti D, Guidolin D, Marzullo A, Nico B, Annese T, Benagiano V et al (2010) Mast cells and angiogenesis in gastric carcinoma. Int J Exp Pathol 91(4):350-356. doi:10.1111/j.1365-2613.2010.00714.x

45. Mogoantă SȘ, Lungu C, Ilie C, Albu DF, Totolici B, Neamțu C et al (2014) Peritumoral inflammatory reaction in colon cancer. Histological and immunohistochemical study. Romanian J Morphol Embryol 55(4):1429-1435

46. Ali G, Boldrini L, Lucchi M, Mussi A, Corsi V, Fontanini G (2009) Tryptase mast cells in malignant pleural mesothelioma as an independent favorable prognostic factor. J Thorac Oncol 4(3):348-354. doi:10.1097/JTO.0b013e3181989ddb

47. Moon TC, St Laurent CD, Morris KE, Marcet C, Yoshimura T, Sekar Y et al (2010) Advances in mast cell biology: new understanding of heterogeneity and function. Mucosal Immunol 3(2): 111-128. doi:10.1038/mi.2009.136

48. Gebhardt T, Lorentz A, Detmer F, Trautwein C, Bektas H, Manns MP et al (2005) Growth, phenotype, and function of human intestinal mast cells are tightly regulated by transforming growth factor beta1. Gut 54(7):928-934. doi:10.1136/gut.2004.054650

49. Ribatti D (2013) Mast cells and macrophages exert beneficial and detrimental effects on tumor progression and angiogenesis. Immunol Lett 152(2):83-88. doi:10.1016/j.imlet.2013.05.003 